Article

\title{
Sustainability in the Aerospace Sector, a Transition to Clean Energy: The $\mathrm{E}^{2}$-EVM Valuation Model
}

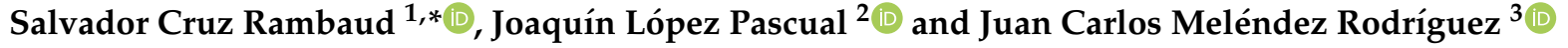 \\ 1 Departamento de Economía y Empresa, Universidad de Almería, 04120 Almería, Spain \\ 2 Departamento de Economía de la Empresa, Universidad Rey Juan Carlos, 28032 Madrid, Spain; \\ joaquin.lopez@urjc.es \\ 3 Departamento de Organización de Empresas y Marketing, Campus de Somosaguas, \\ Universidad Complutense de Madrid, 28223 Madrid, Spain; juanmele@ucm.es \\ * Correspondence: scruz@ual.es
}

Citation: Cruz Rambaud, S.; López Pascual, J.; Meléndez Rodríguez, J.C. Sustainability in the Aerospace Sector, a Transition to Clean Energy: The E²-EVM Valuation Model. Sustainability 2021, 13, 6717. https://doi.org/10.3390/su13126717

Academic Editors: Maria Del

Mar Miralles-Quirós and José Luis Miralles-Quirós

Received: 26 April 2021

Accepted: 10 June 2021

Published: 13 June 2021

Publisher's Note: MDPI stays neutral with regard to jurisdictional claims in published maps and institutional affiliations.

Copyright: (C) 2021 by the authors. Licensee MDPI, Basel, Switzerland. This article is an open access article distributed under the terms and conditions of the Creative Commons Attribution (CC BY) license (https:/ / creativecommons.org/licenses/by/ $4.0 /)$.

\begin{abstract}
Civil aviation is one of biggest industrial contributors to $\mathrm{CO}_{2}$ emissions worldwide. One of the most urgent problems of this sector is providing new technologies to continue operating in a more sustainable environment through a transition to clean energy. The Earned Value Management (EVM) model, as a traditional project management tool, is continuously being revised with new releases and extensions (e.g., ESM, EDM, QEVM, E-EVM, and ZEVM), but to date none of them has applied an expert judgment criterion to be able to modify and anticipate the final result of the project. In such a way, this paper introduces a novel approach to the topic with the so-called Enhanced and Efficient Earned Value Management (denoted $\left.E^{2}-E V M\right)$ model by including this new capability through the real options methodology, thus helping to support the sustainability of the aerospace sector. This research focuses on three main goals: the description of recent green initiatives in the aerospace sector by checking its contribution to reaching the well-known Sustainable Development Goals (SDGs), the development of a new version of the EVM model by applying the real options methodology, and, finally, the financial contribution to the aerospace industry by applying these initiatives and methodologies.
\end{abstract}

Keywords: sustainable development goals; aerospace industry; earned value management; real options

\section{Introduction}

The 2030 Agenda for Sustainable Development has highlighted the need to propose and finance actions necessary to support the Sustainable Development Goals (hereinafter, SDGs). These SDGs show different targets and topics related to defining a framework to promote growth and prosperity and at the same time protect the planet.

These main topics are to tackle climate change, clean energies, health and social protection, transport, science and technology, and, more recently, to define a recovery plan after the COVID-19 pandemic.

Traditionally, the objective of a company has been to obtain the maximum profitability derived from its economic activity. It is well known that only considering this goal can imply forgetting the relevant consequences of human activity over the environment.

The aeronautical sector is not unconnected from sustainability due to the fact that aircraft manufacturing represents a source of activities non-compatible with taking care of the environment.

Therefore, the aerospace industry has the chance to invest in the improvement of its manufacturing process, from an environmental perspective, by reducing gas emissions and noise, recycling residuals, etc. Nowadays, these actions represent an option for this sector but we hypothesize that investing in environmental care may even increase the economic profitability of companies due to people's increasing awareness about climate change. 
This is why our paper introduces the so-called E E $^{2}$ EVM model, where the amount of cash flows involved in the project are affected by the real option to expand the investment intended for constructing aircrafts to be more respectful of the environment. Thus, the information provided by the Net Present Value (NPV) will be more accurate as it includes the flexibility of the company to adapt to the measures needed to care for the environment. This is the main objective of the model proposed in this paper.

New perspectives for the aerospace sector offered by forthcoming European funds might allow us to recover, transform, and boost a highly skilled sector with 870,000 employees across Europe. These companies are at the core of European competitiveness, since their high-tech activities trigger spillover effects on several supply chains and economic sectors [1].

The recent announcement that Iberia and Airbus will join forces to invest $€ 11$ billion into sustainable aviation, the digital transition, and the renewal of fleets is a very good example of sustainability. More specifically, this will empower the Madrid hub by increasing the competitiveness of Madrid (the connection center) and consolidate it as the door of entry to Europe for Latin America and a knot of links between the former area and Asia [2].

This great project responds to these objectives, for which the Iberia and Vueling airlines, both integrated in the International Airlines Group (IAG), Airbus (the European aircraft manufacturer), and firms that manage airports and airspace (Aena and Enaire) have joined forces.

The plan is a commitment to competitiveness on the basis of a more sustainable model that is digital, innovative, and socially responsible. The sector would then contribute to the transformation of the economic model and would incorporate innovation, digitization, and the use of highly qualified resources according to the plan presented. It also highlights the digital impulse and services that would have a strong dynamizing effect on the whole sector and renewable energy entities, with a special focus on small and medium-sized enterprises (SMEs) and public-private partnerships.

In this way, Airbus plans to develop the first zero-emission aircraft with hydrogen as its primary power source, which could enter service by 2035. These designs showcase that decarbonization is possible with the right technology, and that air travel can be greener and more sustainable [3,4]. This part of the plan would cost about $€ 1$ billion [5]. New aircraft, such as the Airbus 350 and the Boeing 787, are up to $30 \%$ more fuel efficient than their predecessors, which is already contributing to a decrease in emissions.

The aeronautics and aerospace industries need to prioritize the availability of ecofriendly fuels, which could cut carbon emissions from airplanes, potentially helping them pollute as little as buses and trains.

The aerospace industry is focusing on reducing fuel consumption by improving fuel efficiency as a good way to reduce greenhouse gases, and some airlines are doing this by reducing the weight on aircraft. Some airlines are looking change consumers' buying habits and make adjustments such as dropping in-flight duty-free sales. This might reduce the need to carry extra inventory, which lowers fuel consumption, and speaks to the modern shopping habits of travelers [6].

Moreover, the aerospace industry is trying to provide locally sourced and seasonal foods in an attempt to reduce the carbon footprint of food transportation. While most lettuce that is transported on airlines is shipped from California or Arizona to its departure airport, Singapore Airlines introduced a "farm-to-plane" concept on the world's longest flight [7].

There is no doubt that a great deal of funding is required to carry out such projects. Institutional investors, mutual and investment funds, and pension funds may be interested in diversifying their portfolios by allocating their investment towards these sustainable aeronautical assets.

Some studies have considered the effect of aviation activities in regards to the triple bottom line (TBL) comprised of economic, social, and environmental factors [8]. 
By creating a suitable legal and financial framework for SDGs related to the aeronautics industry, a lot of funding can be obtained from financial markets and investors.

Existing studies [9-11] have pointed out that environmental sustainability may be achieved through external pressure with the imposition and accomplishment of different policies, regulations, taxations, and other fiscal instruments or by meeting the call for public administrators to implement sustainable practices [12].

On the other hand, the authors in [13] highlight that the aviation industry recognizes the growing and urgent need to save the environment and decrease fuel consumption. It is clear that technology plays a vital role in promoting sustainable development and it is the best way to reduce aviation emissions. In particular, we can see the improvement in new aircraft designs and radical engine advances effectively facilitate $\mathrm{CO}_{2}$ reductions.

As indicated by the authors in [14], the global aviation sector has a key role to play in achieving all SDGs, some in small ways and others with a much more significant influence.

According to the United Nations Office for Outer Space Affairs (UNOOSA), space technologies and data are fundamental to achieving the SDGs: they provide real-time, homogenous information from any location, including remote areas, upon which strategic policy-making decisions can be based, and they are essential to monitoring progress in achieving the SDGs [15].

Airbus, one of the most relevant aerospace companies in the world, has declared the main drivers for the future to be unmanned, autonomous, and connected vehicles with zero emissions to the ecosystem and within an Industry 4.0 environment [16]. The biggest aerospace company in the world, Boeing, is also working in a similar direction by reducing the fuel consumption and $\mathrm{CO}_{2}$ emissions by up to $20 \%$ in a new development of its 787 family of airplanes in order to fulfill the SDGs' requirements [17].

Despite its importance in international business and the previously noted efforts by scholars to clarify the importance, dimensions, and impact of sustainable development for the aviation industry, little progress has been achieved in developing specific management strategies in what has been called the 'green aviation industry' [18]. To promote the sustainable development of the green aviation industry, researchers all over the world have attempted to explore and experiment with new initiatives and models to speed up the green aviation industry's development.

The structure of this paper is as follows. Section 1 describes the framework, research problem, and environment. Section 2 reviews the empirical research on the Sustainable Development Goals in the aerospace industry. Section 3 presents a literature review of the real options methodology's application in several industrial sectors. In Section 4, the new Enhanced and Efficient Earned Value Management (E2-EVM) model is presented by highlighting its main contributions and benefits. Finally, Section 5 summarizes and concludes this study, states its limitations, and provides directions for future research.

\section{The Sustainable Development Goals in the Aerospace Industry}

The aerospace sector is a technology and innovation-based industry in which technological knowledge has been applied in a massive way. According to the Spanish Association of Technological Defense, Aeronautical and Space Companies [19], in 2019 the turnover grew by $10.1 \%$ compared with 2018. The final volume of 2019 is a turnover of 13,400 million euros, with a contribution of $7.3 \%$ of the gross domestic product in Spain. More than $78 \%$ of this turnover belongs to civil and military aviation, which contributed 10,500 million euros.

COVID-19 has hit the manufacturing sector and the aerospace sector in particular. The main contribution to addressing this crisis has been to guarantee the supply of essential products that are needed at any given time and must be one of the pillars that drive the economic recovery. At present, the sector is clearly identifying the engines that will enable us to restart the economy and restore the production rates used before the pandemic [20]. Moreover, Airbus shared with its main contributor to the supply chain updated production plans covering the 2023-2025 period [21]. 
On the other hand, Boeing recently presented the recovery plan for its 737-Max aircraft after the redefinition and new certification of some flight systems [22].

In the previous section, it was identified that the need for the aerospace industry to adapt to SDGs plays an important role. Now, we would like to provide a more quantitative argument that reinforces that statement. According to the International Standard Industrial Classification of all Economic Activities, Revision 4 (United Nations, 2008), the activities related to the aerospace industry are included in Section C (Manufacturing). In addition, according to the Agencia Española de Cooperación Internacional para el Desarrollo [23], the average number of SDGs related to the twenty-one economic sectors is 4.48 , whilst there are six SDGs related to the manufacturing sector (SDGs \#3, \#6, \#8, \#9, \#12, and \#17), a figure that is clearly above the mean.

However, in this research, we focus exclusively on the aerospace industry, which is specifically linked to four of these seventeen SDGs: \#7 (Affordable and Clean Energy), whose target is to ensure access to affordable, reliable, sustainable, and modern energy; \#9 (Industry, Innovation, and Infrastructure), which focuses on building resilient infrastructure, promoting inclusive and sustainable industrialization, and fostering innovation; \#12 (Responsible Consumption and Production), which focuses on ensuring sustainable consumption and production patterns; and, finally, \#13 (Climate Action), which focuses on promoting urgent actions to address climate change and reduce its impacts.

In this section, we propose a relationship between the aerospace industry and the aforementioned SDGs after a literature review, which is summarized in Table 1.

Table 1. Aerospace industry vs. Sustainable Development Goals. Source: Own elaboration.

\begin{tabular}{|c|c|c|c|}
\hline SDG\# & SDG Description & References & Main Topics \\
\hline 7 & $\begin{array}{l}\text { Affordable and Clean } \\
\text { Energy }\end{array}$ & {$[18,24,25]$} & $\begin{array}{l}\text { In situ resources and } \\
\text { mission-critical } \\
\text { consumables for } \\
\text { propulsion }\end{array}$ \\
\hline 9 & $\begin{array}{l}\text { Industry, Innovation, } \\
\text { and Infrastructure }\end{array}$ & {$[8,12,26-29]$} & $\begin{array}{l}\text { Integration and } \\
\text { merging processes in } \\
\text { aviation: Building a } \\
\text { global system }\end{array}$ \\
\hline 12 & $\begin{array}{l}\text { Responsible } \\
\text { Consumption and } \\
\text { Production }\end{array}$ & [30-32] & $\begin{array}{c}\text { Development of } \\
\text { aviation biofuels; } \\
\text { more sustainable test } \\
\text { systems }\end{array}$ \\
\hline 13 & Climate Action & [33-35] & $\begin{array}{c}\text { Development of } \\
\text { complex products, } \\
\text { UAV use for } \\
\text { environmental } \\
\text { features applications, } \\
\text { the CFRP recycling } \\
\text { process }\end{array}$ \\
\hline
\end{tabular}

Related to the seventh SDG, some authors [24] point out that the aerospace industry can provide an important reduction in the cost and risk by producing consumables for exploration beyond Earth. Others [25] have concentrated on empirically applying sustainable development principles to the new radar of the European Space Agency (ESA) with the goal of improving global governance and providing continuity of information, services, knowledge, and data for users.

Regarding the improvement in Industry, Innovation, and Infrastructure (\#9), the authors in [26] consider the aviation sector to be an enabler of the global integration process by implementing communications, strategic management, and advances in technology around the world with a close interface with all other components of the system. Given the interest in exploring the benefits of applying innovation and sustainable industrialization, 
a method for integrating a range of business practices into a common practice, merging process integration, quality management, and supply chain management, is shown in [27] for the Canadian aerospace manufacturer.

An attempt [28] was made to research the manufacturing process with Carbon-FiberReinforced Plastic (CFRP) material under the eco-efficiency criteria, reaching a new model based on lifecycle product and cost analysis. More specifically, in [29] a process for evaluating and selecting a supplier is described within a new sustainable operations scenario in the aerospace industry.

SDG \#12 has been researched by the authors of [30], who deployed new automatic test equipment and program sets based on reliability and maintainability concepts with a key contribution to sustainability. In reviewing methodological issues, the authors in [31] propose a concept of revolution in the aviation industry with the use of renewable jet fuels produced from biomass.

Finally, some authors have contributed with an operational cost reduction for airlines in Brazil through the use of aviation biofuels; currently, this cost represents a global average of $33 \%$ [32].

Concerning Climate Actions (\#13), the authors in [33] deployed in two multinational aerospace companies new concepts and methodologies for complex products, achieving a significant reduction in environment impacts and, therefore, a contribution to help with climate changes. Another innovative proposal involves unmanned aerial vehicles (UAVs), which can reduce the environment impact by making decisions based on a response to potential fields generated by probabilistic maps [34]. More recently, the use of CFRP as a basic material in aircraft-satellite structures has become a common practice in the aerospace sector due to its light weight, mechanical capabilities, and corrosion behavior.

However, researchers [35] observed that these materials are difficult to recycle because the recycling process must be performed under extreme conditions.

\section{Real Options vs. Manufacturing Sectors}

The real options literature has occupied the attention of numerous investigators. Among them and for a general overview (\#MIS) of the real options methodology, see Arnold [36]. In addition, some scholars, such as Kodukula and Papudesu [37], have highlighted the "potential applications of real options in various industries, including aerospace, automotive, banking, chemicals, consumer goods, electronics, insurance, medical products, oil and gas, pharmaceuticals, technology, telecommunications, transportation, etc." Specifically, in the aerospace industry, purchasing options to buy additional aircraft in the future is a usual practice in the airline industry. Thus, if the expected payoff derived from expanding their operations is higher than the purchase price of the aircraft (the strike price), they will exercise the option (similarly to a call option).

Table 2 shows the relevant literature on the application of the real options methodology to different representative industrial sectors.

In the \#AER industrial sector, Peters [38] presents the so-called Datar-Mathews method, which applies real options in order to decide whether Boeing invests or not in unmanned vehicles taking into account that the market of these vehicles is very risky due to "a huge dependence on technological developments, such as aviation control systems, remote sensing, and global positioning". The decision was made under the following assumptions:

- a direct R\&D investment of USD 15 million for the implementation of the technological developments in aviation control systems, remote sensing, and global positioning for 2 years;

- a one-time investment of USD325 million for the launch of the UAV; and

- a discount rate of $15 \%$. 
Table 2. Literature on real options applications to industrial sectors. Source: Own elaboration.

\begin{tabular}{|c|c|c|c|}
\hline$\#$ & $\begin{array}{l}\text { Industrial Sector } \\
\text { Description }\end{array}$ & References & Main Topics \\
\hline MIS & Miscellaneous & {$[36,37]$} & $\begin{array}{l}\text { General overview } \\
\text { and real options } \\
\text { applications }\end{array}$ \\
\hline AER & Aerospace & [38-41] & $\begin{array}{l}\text { Unmanned vehicles } \\
\text { projects, aircraft } \\
\text { purchase/ordering } \\
\text { decision-making } \\
\text { process }\end{array}$ \\
\hline OGM & Oil, Gas, and Mining & [42-47] & $\begin{array}{c}\text { Gold mines in North } \\
\text { America, natural } \\
\text { resources lifecycle } \\
\text { model }\end{array}$ \\
\hline RDI & $\begin{array}{l}\text { Research and } \\
\text { Development and } \\
\text { Innovation }\end{array}$ & [48-52] & $\begin{array}{c}\text { Portfolio of projects, } \\
\text { simulation tool, } \\
\text { management of } \\
\text { uncertainty }\end{array}$ \\
\hline STM & $\begin{array}{c}\text { Strategic } \\
\text { Management }\end{array}$ & [53-56] & $\begin{array}{l}\text { Flexibility in teams, } \\
\text { multinational } \\
\text { corporations, the } \\
\text { supply contracts } \\
\text { process, price } \\
\text { uncertainty }\end{array}$ \\
\hline INB & $\begin{array}{l}\text { Infrastructure and } \\
\text { Building }\end{array}$ & [57-59] & $\begin{array}{l}\text { Public-private } \\
\text { investments and } \\
\text { partnerships, net } \\
\text { present value } \\
\text { enhancement }\end{array}$ \\
\hline ITE & $\begin{array}{c}\text { Information } \\
\text { Technologies and } \\
\text { Entrepreneurship }\end{array}$ & [60-66] & $\begin{array}{c}\text { Technology } \\
\text { investment, the } \\
\text { volatility parameter, } \\
\text { entrepreneurship and } \\
\text { strategic resources }\end{array}$ \\
\hline
\end{tabular}

Although the estimated Net Present Value (NPV) was negative (-USD19 million), the managers decided to ignore this indicator as they were convinced they had the flexibility to respond to the uncertainties in the market. The Datar-Mathews method takes into account the market uncertainty for the NPV analysis. In effect, three different scenarios (optimistic, most likely, and pessimistic) were provided by the managers, giving rise to a triangular distribution for each period. With these probability distributions, managers are able to perform a Monte Carlo simulation in order to obtain the distribution of the PV. Observe that, in this case, any other distribution of the Program Evaluation and Review Techniques (PERT) could be used (for example, a beta distribution). For more details on the calculations, see Mathews [39].

Raynor [40] uses real options to analyze the AlliedSignal Corporation (Allied), a USD15 billion traditional and diversified firm competing primarily in the aerospace industry, with divisions in the chemical, automotive, consumer product, and defense industries. On the other hand, Wang et al. [41] identify the characteristics of the aerospace industry and compare the traditional and modern (strategic) views of capacity planning.

Regarding the \#OGM industrial sector, we can find several research studies and applications, such as [42], which applied real options with a new database concept for making decisions in open/closed gold mines in North America. Cortazar and Casassus [43] developed a new model, giving numerical solutions with consideration of different stages 
with finite resources and a finite capacity. It was applied by taking into account the natural resources lifecycle model. In [44], a new technique was presented for evaluating investments for natural resource projects under certain uncertainties in future revenues. A new approach is described in [45] for evaluating oil properties that combines two methodologies: a decision analysis based on stochastic dynamic programming; and the pricing theory based on financial markets. In addition, the real options methodology has been applied to manage more efficiently the inventories of work-in-progress and final products [46]. Finally, in [47] the investment decision process is applied to the scrapping industrial process.

In the Research, Development, and Innovations fields (\#RDI), there have been some significant applications of the real options methodology. MacMillan and McGrath [48] affirmed that the appropriate management of three types of real options can be conducive to obtaining a portfolio of projects that will deliver today's profit and tomorrow's growth. McGrath and MacMillan [49] applied real options in funding projects because the methodology significantly increases the opportunities to keep the cost at acceptable levels and reduces the risk at the same time. On the other hand, the authors in [50] explore the reduction of time in the execution of a project by using a real options valuation based on a sequential exchange option. Another innovative study analyzed the impact of the investment cost in two firms dedicated to innovation services. This impact was defined with the real options methodology by establishing some differences between these companies and their competitors [51]. A simulation tool was implemented to evaluate patents and patent-protected R\&D projects through a real options approach. The important improvement of [52] is the management of uncertainty in several respects, such as cash flows and the estimation of the completion of the project. This study also establishes an alert warning system in the project when it turns out that the cost will be larger than scheduled.

Focusing on the Strategic Management Sector (\#STM), there are some significant articles to mention. The real options methodology has been revised from the strategic management point of view, showing new ways of working through the reduction of tensions and increasing the flexibility of teams [53]. Tong and Reuer [54] report the application of the real options methodology in multinational corporations, giving a new approach consisting in the coordination of costs surrounding international operations. In [55], it is shown that the use of the real options approach does not always result in a benefit. In this case, the article describes problems associated with an investment in a R\&D project after the application of real options. Li and Kouvelis [56] also applied real options in the valuation of different types of supply contract processes. Common and standard variables in this type of contract are time, cost, flexibility, and quality. All of them can be modified with this new approach, and the uncertainty in the final price of the order always remains under control.

In the Infrastructure and Building (\#INB) sector, we can also find some studies, such as that of Power et al. [57], who investigate new partnerships in this sector by combining public and private investments through strategic options embedded in contracts. This approach is feasible as this new relationship gives benefits to both parties. On the other hand, [58] shows that the early termination of public-private partnerships in large infrastructure projects frequently occurs because the management of risk is not properly considered. The application of the real options methodology could improve this relationship. The traffic demand in the Indian highway sector is considered a critical risk; for this, real options are used to improve this problem by making an analogy to financial options, i.e., using in this real-life case study the binomial lattice method indicates an enhancement to the net present value of the project [59].

We also found relevant studies when delving into Information Technologies and Entrepreneurship (\#ITE), such as the use of real options to add value in the investment decision process under an uncertainty framework [60]. Benaroch merged in his research different parameters (scope, cost, stakeholder management, chronograms, and flexibility) by designing a new model to maximize the value of a technology investment [61] and 
applied this model to an electronic banking network in New England [62]. A combination of the real options methodology, with a growth rate and a volatility parameter, and capitalbudgeting techniques was applied by Schwartz and Moon to an internet company [63]. The collaborative innovation way of working is significantly used in entrepreneurship and strategic companies. Their knowledge, expertise, and opportunities can be improved through the use of the real options theory, supporting the process of evaluation of innovative ideas [64]. There are two major competing procedures for evaluating risky projects in which managerial flexibility plays an important role: one is a decision analysis based on stochastic dynamic programming and the other is the option pricing theory (or contingent claims analysis) based on the no-arbitrage theory of financial markets [65]. Finally, Ireland et al. [66] combined opportunity and advantage-seeking behaviors in the management of strategic resources and in the development of innovations.

\section{Defining the Enhanced and Efficient Earned Value Management $\left(E^{2}\right.$-EVM) Model: An Application of Real Options to the Aerospace Industry}

Nowadays, all economic sectors in a country must be oriented towards the fulfillment of the well-known SDGs. Indeed, this is an unstoppable tendency. However, depending on the specific country, some sectors can be made to satisfy certain sustainable requirements according to appropriate domestic and/or international regulations. However, most companies are becoming more aware of environmental problems and will take the initiative to undertake sustainable projects. Undoubtedly, these companies will be able to obtain a competitive advantage derived from their own strategic decisions and based on their operational flexibility (see Figure 1). This is the added value that this section aims to determine when calculating the net present value of a project endowed with such flexibility.

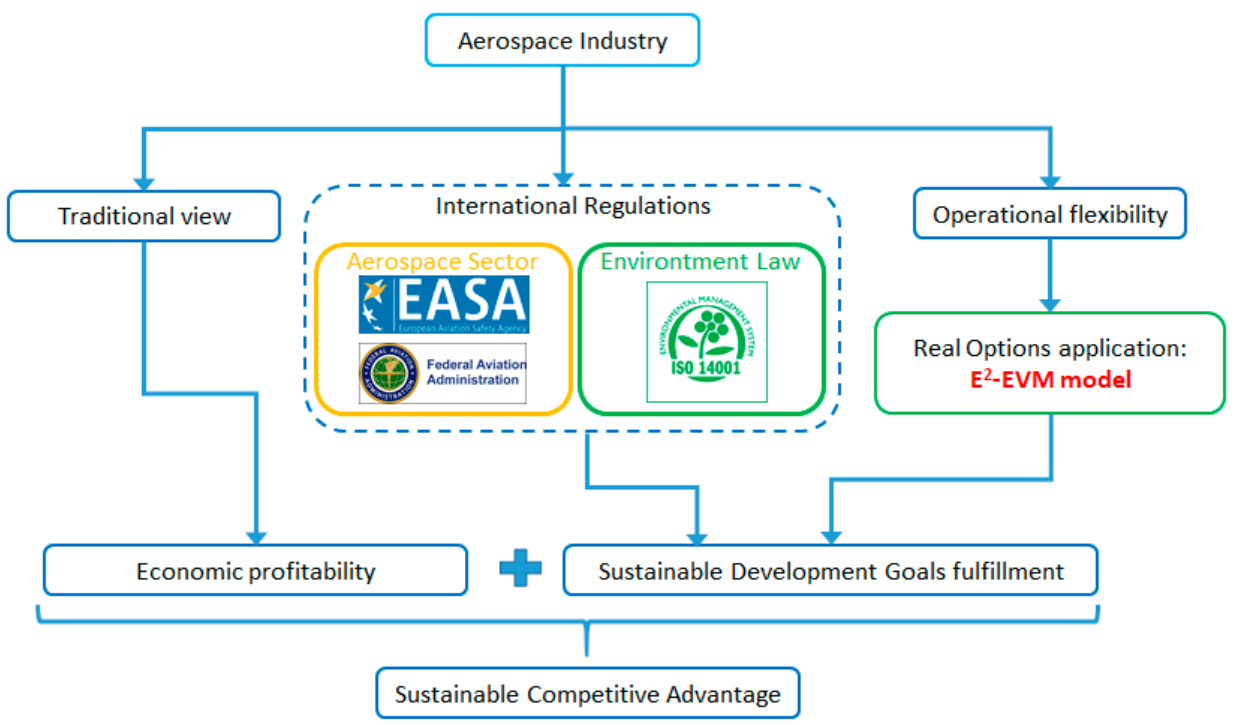

Figure 1. Overview of the aerospace industry. Source: Own elaboration.

In projects appraisal, the well-known Net Present Value (NPV) method consists in amounting, at instant 0 , the present value of cash flows expected at the end of all periods included in the projected duration of the involved investment:

$$
\mathrm{NPV}=-I_{0}+\sum_{k=1}^{n} Q_{k}\left(1+i_{k}\right)^{-k}+V_{n}\left(1+i_{n}\right)^{-n},
$$

where:

- $I_{0}$ is the initial investment that is necessary to carry out the project,

- $n$ is the expected duration of the project, 
- $Q_{k}$ is the cash flow expected at time $k(k=1,2, \ldots, n)$,

- $i_{k}$ is the interest rate corresponding to period $k(k=1,2, \ldots, n)$, and

- $V_{n}$ is the residual value of the project expected at time $n$.

Despite its simplicity, Equation (1) is mostly used in contexts in which a valuation process is required. However, it is necessary to take into account the fact that, in the bestcase scenario, it is not possible to estimate the duration of the investment and, moreover, there is a lot of uncertainty when eliciting the distribution functions of the cash flows and the residual value. Finally, the use of different rates of interest requires prior knowledge of the yield curve. Therefore, the only parameter of Equation (1) known with certainty is the initial investment.

For all these reasons, we are going to simplify Equation (1) by assuming that the interest rate is constant. Moreover, by removing the residual value, this expression remains as:

$$
\mathrm{NPV}=-I_{0}+\sum_{k=1}^{n} Q_{k}(1+i)^{-k}
$$

Apart from the aforementioned limitations of the NPV, derived from the lack of information about the involved variables, there is another characteristic of the project that could be included in the classical expression of the NPV, i.e., its ability to be adapted to future circumstances affecting the management of the project. In other words, the potential flexibility of the project is not included in the expression of the NPV. Each side of this flexibility is called a real option. For example, we can cite (the list is not exhaustive) the option to defer [67], expand [68], reduce [69], or abandon the project [70].

The theory of real options aims to incorporate the flexibility of a project into the traditional expression of its NPV, giving rise to a new NPV. Observe that the traditional NPV is a kind of "picture" of the project at time 0 , whereby it will be labeled as "static NPV". On the contrary, the NPV including real options quantifies the ability of the project to be adapted to future contingencies, whereby it will be labeled as "dynamic NPV". Logically, the so-defined NPVs satisfy the following inequality:

$$
\text { Dynamic NPV > Static NPV. }
$$

Obviously, the value of the real option shown by the project will be the difference between the former NPVs, that is to say,

$$
\text { Value of the real option }=\text { Dynamic NPV }- \text { Static NPV. }
$$

It is evident that real options make more sense in innovative industries such as the aerospace sector, where the volatility of returns is higher. In what follows, we will write Equation (2) in the following way:

$$
\mathrm{NPV}=-I_{0}+V_{0},
$$

where $V_{0}$ is the Present Value, defined by:

$$
V_{0}=\sum_{k=1}^{n} Q_{k}(1+i)^{-k}
$$

In the rest of this paper, we will assume that, in order to depict the possible evolution of $V_{0}$, it must be multiplied by an upward coefficient, denoted by $u$, and by a downward coefficient, denoted by $d$, giving rise to a binomial tree. Figure 2 shows the binomial tree for two periods with the probabilities associated with each scenario. 


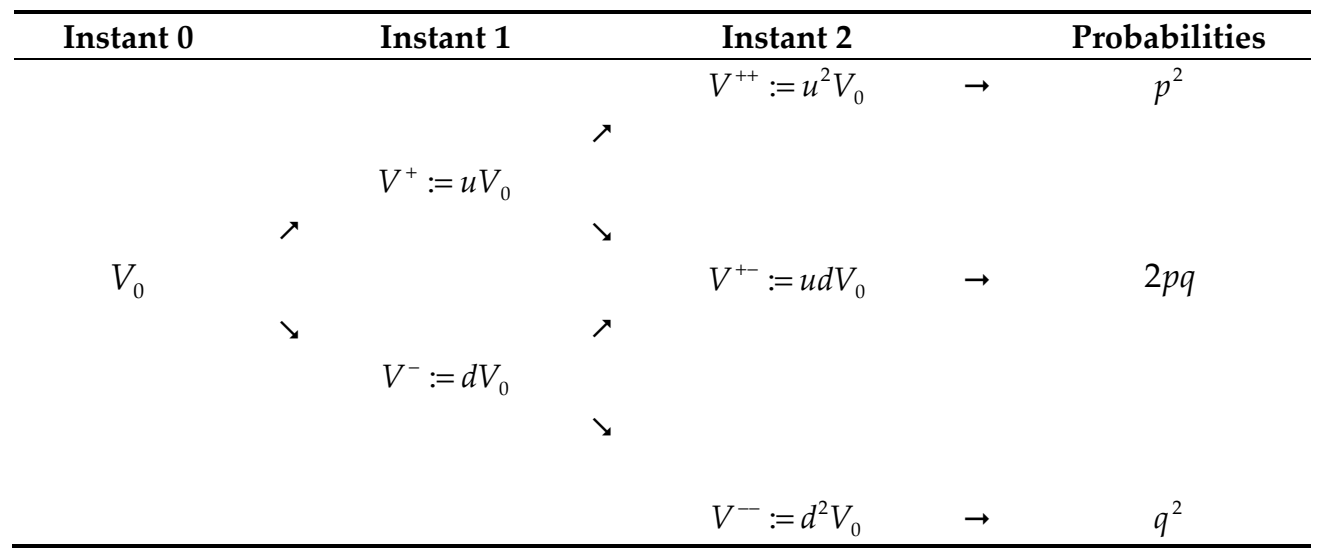

Figure 2. Binomial tree for two periods. Source: Own elaboration.

The following items exhibit the relationships between the variables involved in Figure 1:

- Upward coefficient: $u=\exp \{\sigma\}$, where $\sigma$ is the volatility of returns in the industry.

- Downward coefficient: $d=\frac{1}{u}$.

- Probability of the upward scenario: $p=\frac{\left(1+r_{f}\right)-d}{u-d}$, where $r_{f}$ is the risk-free interest rate.

- Probability of the downward scenario, $q=1-p$.

The steps to determine the value of a real option are the following:

- $\quad$ Step \#1: Determine the parameters involved in Figure 1.

- $\quad$ Step \#2: Calculate the static NPV.

- $\quad$ Step \#3: Calculate the NPV by assuming the real option and by only considering the favorable scenarios, that is to say, the dynamic NPV.

- $\quad$ Step \#4: Calculate the value of the real option as the difference between the results derived from steps \#3 and \#4 (see Equation (4)).

The aim of this paper is to apply the methodology of real options to the aerospace industry and, more specifically, the model defined by Meléndez Rodríguez et al. [71], to certain variables involved in the so-called Enhanced Earned Value Management (E-EVM) model [72], giving rise to the so-called Enhanced and Efficient Earned Value Management $\left(E^{2}-E V M\right)$ model, which will incorporate the capacity of the project to be adapted to the Sustainable Development Goals. That is, there are a lot of persistent airborne applications and some new ones for which lighter-than-air hybrid vehicles are a real option, as indicated by the Royal Academy of Engineering and Royal Aeronautical Society [73]. On the other hand, Casault [74] claims that "[d]ue to its strong hierarchical structure, the aerospace and defense sector was targeted as an ideal test-bed candidate for the use of real options pricing of innovation".

\subsection{The Model}

The need for the aerospace industry to adapt to SDGs has been justified in Table 1. Therefore, the aerospace sector must invest strongly in trying to achieve the SDGs related to its economic activity. At the beginning, this kind of investment is an option for companies but investing in sustainable development is a way to improve their image, open new markets, and, consequently, attract new clients. Moreover, do not forget that some of the incremental investment would be subsidized by the central government of each country. To summarize, investing in the achievement of the SDGs related to the aerospace industry is an option to expand its economic activity via innovative investments.

Beyond this, the next step would be to identify the variables involved in the analysis of this specific option. According to López Pascual et al. [72], the most suitable variables for the treatment of options in this context are the following (extracted from the so-called Enhanced Earned Value Management (E-EVM) model):

1 The Earned Value (denoted by EV), given by the following equation: 


$$
\text { EV }=\text { Project progress } \times \text { Planned Value. }
$$

2 The original project budget, called the Budget at Completion $(B A C)$.

With respect to the volatility of the aerospace industry, we can use this parameter generated by the so-called Dow Jones U.S. Aerospace and Defense Index. The annual volatility of this index is $18.36 \%$. Another way to determine the volatility is by means of a Bayesian analysis. In effect, if we have the pessimistic $\left(E V^{p}\right)$, optimistic $\left(E V^{o}\right)$, and more likely $\left(E V^{m}\right)$ values of the earned value, we can obtain the volatility (variance):

$$
\sigma^{2}=\frac{\left(E V^{o}-E V^{p}\right)-\left(E V^{m}-E V^{p}\right)\left(E V^{o}-E V^{m}\right)}{18},
$$

if the variable $E V$ follows a triangular distribution, and:

$$
\sigma^{2}=\frac{\left(E V^{o}-E V^{p}\right)^{2}}{36}
$$

if the variable $E V$ follows a beta distribution, used in the PERT methodology.

Having estimated the volatility to be applied to the methodology of options, we have to estimate the incremental budget at completion $\left(B A C_{E}\right)$, which is necessary to the fulfillment of certain SDGs. Moreover, this incremental investment is going to generate an additional rate $x$ of cash flows (given by the variable $E V$ ). Thus, the $E V$ of the project with the option to expand included is given by the discounted mathematical expectation of the following random variable:

$$
P V^{*}=\left\{\begin{array}{cc}
V_{0} u^{2}+\max \left\{-B A C_{E}+V_{0} u^{2} x, 0\right\}, & \text { with probability } p^{2} \\
V_{0} u d+\max \left\{-B A C_{E}+V_{0} u d x, 0\right\}, & \text { with probability } 2 p q \\
V_{0} d^{2}+\max \left\{-B A C_{E}+V_{0} d^{2} x, 0\right\}, & \text { with probability } q^{2}
\end{array}\right.
$$

where $V_{0}$ is the present value of the project without the option to expand. Finally, $N P V^{*}:=-B A C_{0}+$ $P V^{*}$ is the net present value of the investment including the option to expend, where $B A C_{0}$ is the budget at completion at time 0 .

Obviously, the use of the just-defined new variables $E V^{*}$ and $B A C_{E}$ is the conceptual basis of the novel Enhanced and Efficient Earned Value Management ( $E^{2}$-EVM) model introduced in this manuscript.

\subsection{A Numerical Example}

For the sake of simplicity, we are going to assume a project of three years' duration. The planned value at the end of the project is 1,932,240 euros. An expert has been asked to provide an optimistic, a pessimistic, and the most likely values of the earned values $(E V)$ at the end of each year. The information is displayed in Table 3.

Table 3. Earned values at the end of each year. Source: Own elaboration.

\begin{tabular}{cccc}
\hline Values $(\boldsymbol{(})$ & Year \#1 & Year \#2 & Year \#3 \\
\hline Optimistic & 713,400 & $1,090,680$ & $1,541,580$ \\
Pessimistic & 704,700 & $1,081,620$ & $1,534,080$ \\
Most likely & 712,020 & $1,089,300$ & $1,540,200$ \\
\hline
\end{tabular}

Taking into account that the earned values are cumulative figures, we are going to calculate the cash flows generated at the end of each year as the difference between an earned value and the former one, giving rise to the result shown in Table 4. 
Table 4. Cash flows generated at the end of each year. Source: Own elaboration.

\begin{tabular}{cccc}
\hline Values $\mathbf{( € )}$ & Year \#1 & Year \#2 & Year \#3 \\
\hline Optimistic & 713,400 & 377,280 & 450,900 \\
Pessimistic & 704,700 & 376,920 & 452,460 \\
Most likely & 712,020 & 377,280 & 450,900 \\
\hline
\end{tabular}

By using the expression of the mean in a triangular distribution, we calculated the average cash flows of each year and then the volatility implicit in the duration of the project $(30.10 \%)$. Before continuing the development of this numerical example, we are going to determine the static present value of the project by discounting the formerly calculated average cash flows (with a risk-free interest rate of $3 \%$ ):

$$
P V=1,796,894.77 \text { euros. }
$$

The following parameters are necessary to construct the binomial tree of this project:

- $u=\exp \{\sigma\}=\exp \{0.3010\}=1.3512$.

- $d=\frac{1}{u}=0.74$.

- $\quad p=\frac{\left(1+r_{f}\right)-d}{u-d}=\frac{1.03-0.74}{1.3512-0.74}=0.4745$.

- $q=1-p=0.5255$.

Therefore, the binomial tree is as displayed in Figure 3.

\begin{tabular}{|c|c|c|c|c|c|c|}
\hline Instant 0 & Instant 1 & Instant 2 & & Instant 3 & & Probabilities \\
\hline \multirow{11}{*}{$1,796,894.77$} & & & & $4,432,834.87$ & $\rightarrow$ & 0.1068 \\
\hline & & & $r$ & & & \\
\hline & & $3,280,665.24$ & & & & \\
\hline & & $x$ & $\searrow$ & & & \\
\hline & $2,427,964.21$ & & & $2,427,964.21$ & $\rightarrow$ & 0.3549 \\
\hline & $>$ & 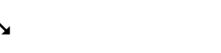 & $r$ & & & \\
\hline & & $1,796,894.77$ & & & & \\
\hline & $y$ & $\lambda$ & 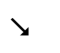 & & & \\
\hline & $1,329,702.13$ & $y$ & $\lambda$ & $1,329,702.13$ & $\rightarrow$ & 0.3931 \\
\hline & & $983,979.58$ & & & & \\
\hline & & & $y$ & $728,144.89$ & $\rightarrow$ & 0.1451 \\
\hline
\end{tabular}

Figure 3. Binomial tree corresponding to the example. Source: Own elaboration.

On the other hand, the budget at completion of this project is 672,000 euros. Now, for the fulfilment of sustainable development goals, the company has the option to expand the project in the third year by making an additional investment of 600,000 euros. As a consequence of the increase in the awareness of its clients, the company expects to earn $25 \%$ more. The new binomial tree is displayed in Figure 4. 


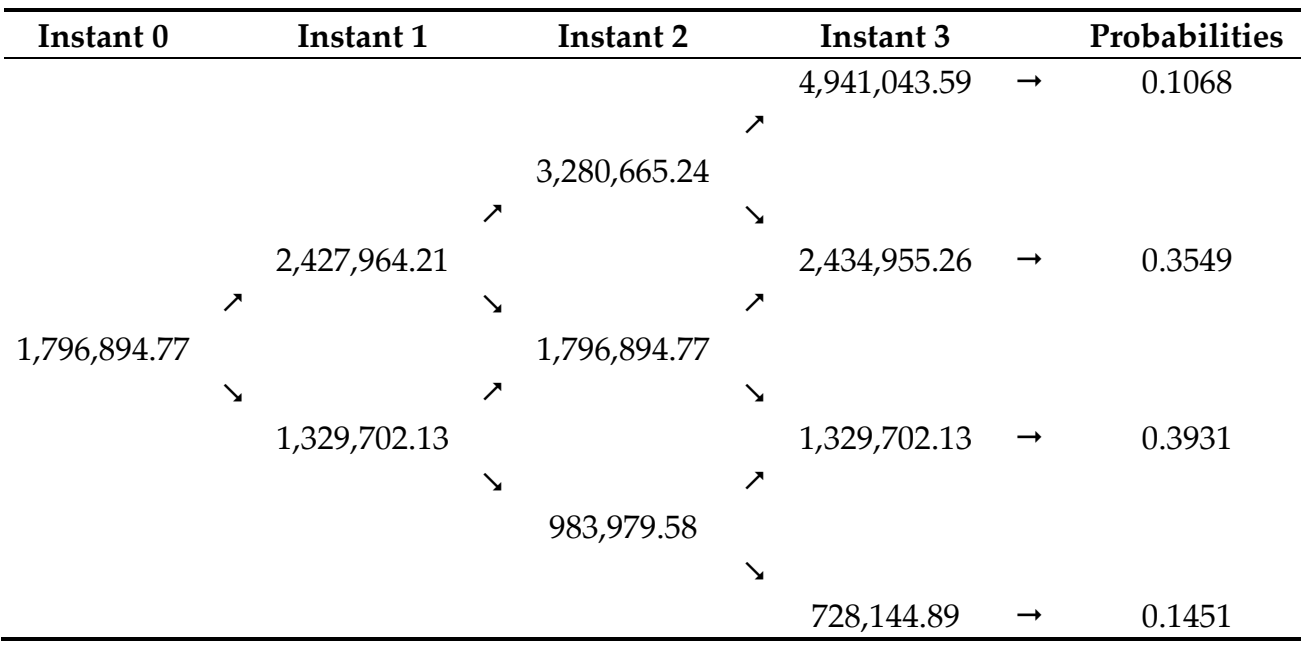

Figure 4. Binomial tree corresponding to the example. Source: Own elaboration.

Therefore, the dynamic NPV is 2,020,227.60 euros and the value of the option to expand is 2,020,227.60-1,796,894.77 $=223,332.83$ euros. Observe that an increase in the NPV will facilitate the decision-making in favor of a more sustainable investment.

As a final view and for further clarification, Table 5 shows the correspondence between the parameters of the generic real options and the just-defined $E^{2}$-EVM model.

Table 5. Main parameters of real options and the $\mathrm{E}^{2}$-EVM model. Source: Own elaboration.

\begin{tabular}{cccc}
\hline & General & E $^{2}$-EVM & \\
\hline Initial Investment & $I_{0}$ & $B A C_{0}$ & Budget at Completion \\
\hline Cash Flow & $Q_{k}$ & $E V_{0}$ & Earned Value \\
\hline Net Present Value & $\mathrm{NPV}$ & $E V^{*}$ & $\begin{array}{c}\text { Earned Value }+ \\
\text { Option to Expand }\end{array}$ \\
\hline
\end{tabular}

\section{Conclusions, Limitations, and Future Research}

Traditionally, the well-known Earned Value Management (EVM) model has been used by the aerospace industry when monitoring the degree of fulfillment of the different tasks and phases that compose the construction of an airplane. The analysis of the existing literature on this topic has shown the introduction of several extensions of this model, such as ESM [75-77], EDM [78], QEVM [79], E-EVM [62], and ZEVM [80]. One of them, the so-called Enhanced Earned Value Management (E-EVM) model, is a recent complement of the EVM in such a way that all the parameters involved in this methodology are considered in terms of both time and money [71,72]. This is a noteworthy variant of the EVM because the E-EVM allows us to visualize delays in the completion of tasks and also estimate the provisional gains and losses at each stage of the analyzed project.

However, none of the aforementioned extensions, the E-EVM model included, has taken into account the flexibility of the project to be adapted to the fulfillment of the wellknown Sustainable Development Goals promoted by the United Nations. Indeed, this is an important feature of the aerospace industry, whose contribution to air contamination is very high. Nevertheless, it should be pointed out that this sector is making a huge effort to research clean energy as an alternative to fossil fuels [81,82].

The above paragraphs justify the proposal, in this paper, of the novel Enhanced and Efficient Earned Value Management (denoted E2-EVM) model, which is a novel extension of the EVM and, more specifically, of the E-EVM, which takes into account the flexibility of the project to be adapted to the SDGs directly linked to the aerospace industry. Consequently, apart from the anticipated diagnosis of potential delays and losses incurred by the project, the $\mathrm{E}^{2}-\mathrm{EVM}$ incorporates in its parameters (specifically, the Earned Value, EV) the flexibility 
of the project to be adapted to the recommended SDGs, thus contributing to a more modern, efficient, and sustainable sector.

Obviously, the flexibility of a project must be described by using real options. This paper is not an exemption and provides a detailed description of the steps to be followed in order to implement this methodology into the assessment of the efficiency from a sustainable point of view. Therefore, this study represents a novel approach that also can help revisit existing literature on the topic.

We would also like to highlight some limitations of this study due to the very specific characteristics of the aerospace sector. The full industrial implementation of the SDGs will require the application of time-consuming processes by the European Aviation Safety Agency (EASA) and the Federal Aviation Administration (FAA) [83,84].

Further research is desirable and feasible, especially with respect to exploring the Bayesian inference methodology [85] in order to improve the accuracy of the decisionmaking process and add the judgments of experts related to this aerospace sector. In addition, the production systems in this industry are always pursuing the "zero defects" target. It will be important to make efforts to further research the significant improvement of the model described in this article through incorporation of "learning curves" effects to increase the global performance of the project.

Author Contributions: The individual contribution of each author has been as follows: writing, methodology, investigation, formal analysis, S.C.R.; writing, conceptualization, investigation and methodology supervision, J.L.P.; writing, formal analysis, software, data curation and validation, J.C.M.R. All authors have read and agreed to the published version of the manuscript.

Funding: This research received no external funding.

Institutional Review Board Statement: Not applicable.

Informed Consent Statement: Not applicable.

Data Availability Statement: The data used in this paper were obtained from simulations based on real information.

Acknowledgments: We are very grateful for the comments and suggestions offered by the three anonymous referees.

Conflicts of Interest: The authors declare there are no conflict of interest.

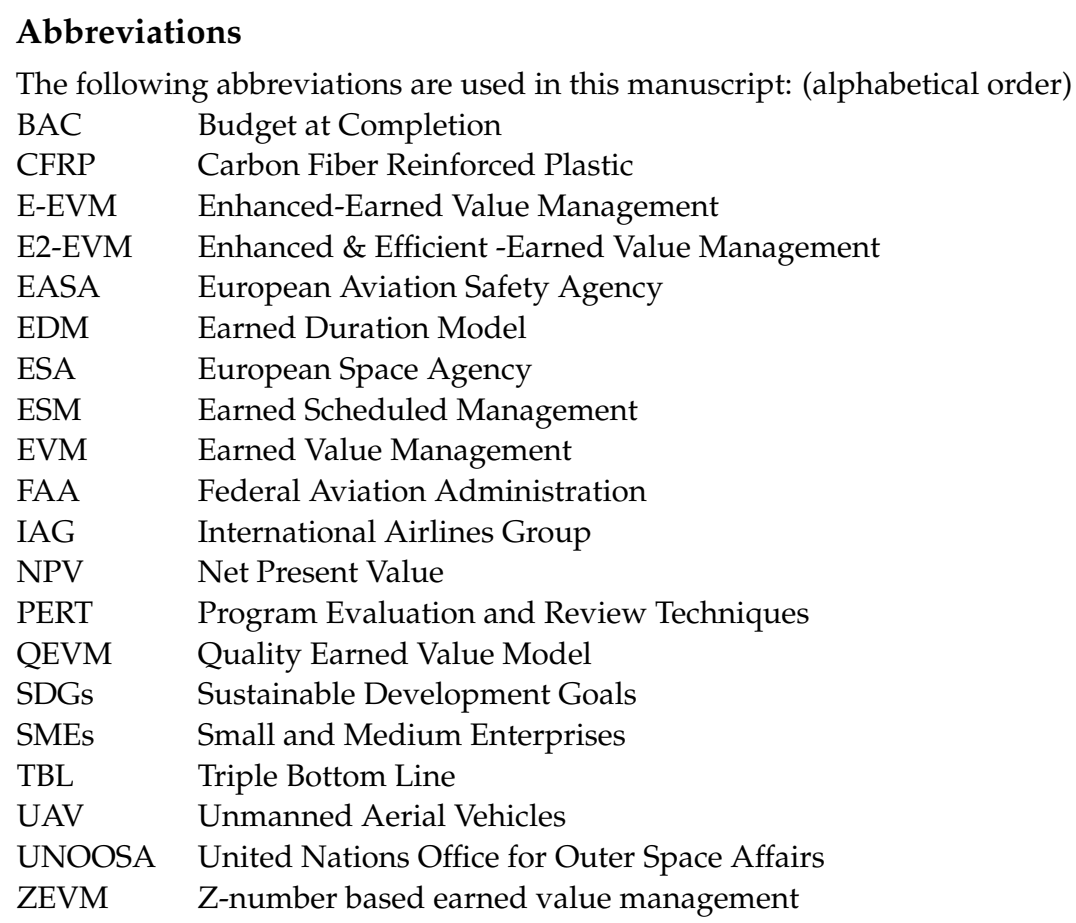




\section{References}

1. The Aerospace and Defence Industries Association of Europe. 2020. Available online: https://www.asd-europe.org/sites/ default/files/atoms/files/ASD_FactsFigures_2020.pdf (accessed on 20 April 2021).

2. The Limited Times: Iberia and Airbus Join Forces to Invest 11,000 Million in Sustainable Aviation. 2021. Available online: https:/ / newsrnd.com/business/2021-02-15-\%0A---iberia-and-airbus-join-forces-to-invest-11-000-million-in-sustainableaviation-\%0A--.SkbWhTLPZO.html (accessed on 24 April 2021).

3. Airbus: Decarbonisation: Towards More Sustainable Air Travel for Future Generations. 2021. Available online: https://www. airbus.com/company/sustainability/environment/decarbonisation.html (accessed on 24 April 2021).

4. European Union Aviation Safety Agency (EASA): EASA Completes First CO2 Emissions Certification for Airbus A330-900. 2021. Available online: https://www.easa.europa.eu/newsroom-and-events/press-releases/easa-completes-first-co2-emissionscertification-airbus-a330-900 (accessed on 30 May 2021).

5. Airbus: Airbus Reveals New Zero-Emission Concept Aircraft. 2020. Available online: https://www.airbus.com/newsroom/ press-releases/en/2020/09/airbus-reveals-new-zeroemission-concept-aircraft.html (accessed on 24 April 2021).

6. Smartvel: Sustainability in the Airline Industry: 8 Eco Trends from Top Players. 2021. Available online: https://blog.smartvel. $\mathrm{com} / \mathrm{blog} /$ sustainability-in-the-airline-industry-8-eco-trends-from-top-players (accessed on 30 May 2021).

7. Insider: Singapore Airlines, One of the Most Ritzy Airlines in the World, is Partnering with a High-Tech Urban Farm to Make Sure it Serves the Best Meal on Every Flight. Take a look inside the futuristic operation. 2021. Available online: https:/ / www.businessinsider.com/farm-to-plane-singapore-airlines-aerofarms-local-2019-9 (accessed on 30 May 2021).

8. Walala, M.; Mutinda, E.M. Evaluation of sustainable development in aviation industry: A case study of Kenya Airways (KQ) and Eldoret international airport. J. Econ. Sustain. Dev. 2013, 4, 61-74.

9. Graham, B.; Guyer, C. Environmental sustainability, airport capacity and European air transport liberalization: Irreconcilable goals? J. Transp. Geogr. 1999, 7, 165-180. [CrossRef]

10. Lu, C. The implications of environmental costs on air passenger demand for different airline business models. J. Air Transp. Manag. 2009, 15, 158-165. [CrossRef]

11. Forsyth, P. Environmental and financial sustainability of air transport: Are they incompatible? J. Air Transp. Manag. 2011, 17, 27-32. [CrossRef]

12. Lutte, R.K.; Bartle, J.R. Sustainability in the Air: The modernization of international air navigation. Public Works Manag. Policy 2017, 22, 322-334. [CrossRef]

13. Mrazova, M. Sustainable development-the key for green aviation. Incas Bull. 2014, 6, 109-122. [CrossRef]

14. Tegizbekova, Z. Sky-high sustainability: Aviation's lofty role in reaching the United Nations' sustainable development goals. Air Space Law 2019, 19, 7-50.

15. Beast: Space Activities to Achieve Sustainable Development Goals. 2019. Available online: https://www.beastmagazine.lu/ space-activities-to-achieve-sustainable-development-goals/ (accessed on 20 April 2021).

16. Airbus: Future Concepts. A Fresh Approach to Aircraft Design \& Materials. 2021. Available online: https://www.airbus.com/ innovation/future-concepts.html (accessed on 20 April 2021).

17. Boeing: 2014 Environment Report. Built a Better Panet. 2014. Available online: https://www.boeing.com/aboutus/environment/ environment_report_14/5.1_performance_summary.html (accessed on 20 April 2021).

18. Rui, Q.; Shuhua, H.; Xin, C.; Zhiyi, M. Green aviation industry sustainable development towards an integrated support system. Bus. Strategy Environ. 2021. [CrossRef]

19. TEDAE: 2019 Anuario del Sector Espacial en España. 2020. Available online: https://www.tedae.org/es/noticias/tedae-presentael-anuario-2019-del-sector-espacial-espanol (accessed on 30 May 2021).

20. BBC: Airbus Ramps up Production as It Eyes Post-Covid Recovery. 2021. Available online: https://www.bbc.com/news/ business-57267194 (accessed on 30 May 2021).

21. Airbus: Airbus Provides Suppliers with an Update on Production Plans. 2021. Available online: https://www.airbus.com/ newsroom/press-releases/en/2021/05/airbus-provides-suppliers-with-an-update-on-production-plans.html (accessed on 30 May 2021).

22. Aviation Week: 737 Max Recovering, but Production-Rate Target Ambitious, Analyst Says. 2021. Available online: https: / / aviationweek.com/mro/aircraft-propulsion/737-max-recovering-production-rate-target-ambitious-analyst-says (accessed on 30 May 2021).

23. Agencia Española de Cooperación Internacional para el Desarrollo. Estudio sobre la contribución de la empresa a la Agenda de los Objetivos de Desarrollo Sostenible (ODS). In Colección Empresa y Desarrollo; AECID: Madrid, Spain, 2017.

24. Sanders, G.B.; Larson, W.E. Progress made in lunar in situ resource utilization under NASA's exploration technology and development program. J. Aerosp. Eng. 2013, 26. [CrossRef]

25. Snoeij, P.; Attema, E.; Davidson, M.; Duesmann, B.; Floury, N.; Levrini, G. Sentinel-1 radar mission: Status and performance. IEEE Aerosp. Electron. Syst. Mag. 2010, 25, 32-39. [CrossRef]

26. Bonser, M.P. Global aviation system: Towards sustainable development. Int. J. Aviat. Aeronaut. Aerosp. 2019, 6, 8. [CrossRef]

27. Laframboise, K.; Reyes, F. The digitization of an aerospace supply network. Int. J. Enterp. Inf. Syst. 2007, 3, 68-89. [CrossRef]

28. Al-Lami, A.; Hilmer, P.; Sinapius, M. Eco-efficiency assessment of manufacturing carbon fiber reinforced polymers (CFRP) in aerospace industry. Aerosp. Sci. Technol. 2018, 79, 669-678. [CrossRef] 
29. Lin, C.-T.; Hung, K.-P.; Hu, S.-H. A Decision-making model for evaluating and selecting suppliers for the sustainable operation and development of enterprises in the aerospace industry. Sustainability 2018, 10, 735. [CrossRef]

30. Hullet, J.N. Ask the user: A practical approach to test program set development. IEEE Aerosp. Electron. Syst. Mag. 2005, 20, 3-7. [CrossRef]

31. Cavalett, O.; Cherubini, F. Contribution of jet fuel from forest residues to multiple sustainable development goals. Nat. Sustain 2018, 1, 799-807. [CrossRef]

32. Cortez, L.; Nigro, F.; Nogueira, L.; Nassar, A.; Cantarella, H. Perspectives for sustainable aviation biofuels in Brazil. Int. J. Aerosp. Eng. 2015. [CrossRef]

33. Brookes, N.J.; Morton, S.C.; Grossman, S.; Joesbury, P.; Varnes, D. Analyzing social capital to improve product development team performance: Action-research investigations in the aerospace industry With TRW and GKN. IEEE Trans. Eng. Manag. 2007, 54, 814-830. [CrossRef]

34. Shem, A.G.; Mazzuchi, T.A.; Sarkani, S. Addressing uncertainty in UAV navigation decision-making. IEEE Trans. Aerosp. Electron. Syst. 2008, 44, 295-313. [CrossRef]

35. Rodrigues, V.; Kennedy, R.; Chang, M. Strategy and management for the recycling of carbon fiber-reinforced polymers (CFRPs) in the aircraft industry: A critical review. Int. J. Sustain. Dev. World Ecol. 2017, 24, 214-223.

36. Arnold, T. A Pragmatic Guide to Real Options; Palgrave Macmillan: New York, NY, USA, 2014.

37. Kodukula, P.; Papudesu, C. Project Valuation Using Real Options. A Practitioner's Guide; J. Ross Publishing, Inc.: Fort Lauderdale, FL, USA, 2006.

38. Peters, L. Real Options Illustrated; Springer: Cham, Switzerland, 2016.

39. Mathews, S. Valuing risky projects with real options. Res. Technol. Manag. 2009, 52, 32-41. [CrossRef]

40. Raynor, M.E. Real organizations for real options: The administrative implications of creating and exercising real options through corporate diversification. In Proceedings of the 4th Annual Conference on Real Options: Theory meets Practice, University of, Cambridge, Cambridge, UK, 22 June 2000.

41. Wang, K.; Buxton, D.; Farr, R.; MacCarthy, B. Strategic capacity planning in the aerospace industry. In Proceedings of the ICRM 2007-4th International Conference on Responsive Manufacturing, Nottingham, UK, 17-19 September 2007.

42. Moel, A.; Tufano, P. When are real options exercised? An empirical study of mine closings. Rev. Financ. Stud. 2002, 15, 35-64. [CrossRef]

43. Cortazar, G.; Casassus, J. A compound option model for evaluating multistage natural resource investments. Project Flexibility, Agency, and Competition: New Development in the Theory and Application of Real Options; Oxford University Press: New York, NY, USA, 2000; pp. 205-223.

44. Brennan, M.J.; Schwartz, E.S. Evaluating natural resource investments. J. Bus. 1985, 58, 135-157. [CrossRef]

45. Smith, J.E.; McCardle, K.F. Valuing oil properties: Integrating option pricing and decision analysis approaches. Oper. Res. 1998, 46, 198-217. [CrossRef]

46. Cortazar, G.; Schwartz, E.S. A Compound option model of production and intermediate inventories. J. Bus. 1993, 66, 517-540. [CrossRef]

47. McDonald, R.; Siegel, D. The value of waiting to invest. Qual. J. Econ. 1986, 101, 707-727. [CrossRef]

48. MacMillan, I.; McGrath, R.G. Crafting R\&D project portfolios. Res. Technol. Manag. 2002, 45, 48-59.

49. McGrath, R.G.; MacMillan, I. Assessing technology projects using real options reasoning. Res. Technol. Manag. 2000, 43, 35-49. [CrossRef]

50. Lee, J.; Paxson, D. Valuation of R\&D real American sequential exchange options. Res. Dev. Manag. 2001, 31, 191-201.

51. Pawlina, G.; Kort, P. Real options in an asymmetric duopoly: Who benefits from your competitive disadvantage? J. Econ. Manag. Strategy 2006, 15, 1-35. [CrossRef]

52. Schwartz, E. Patents and R\&D as real options. Econ. Notes 2004, 33, 23-54.

53. Trigeorgis, L.; Reuer, J. Real options theory in strategic management. Strateg. Manag. J. 2017, 38, 42-63. [CrossRef]

54. Tong, T.; Reuer, J. Real options in multinational corporations: Organizational challenges and risk implications. J. Int. Bus. 2007, 38, 213-230. [CrossRef]

55. Bowman, E.; Moskowitz, G. Real options analysis and strategic decision making. Org. Sci. 2001, 12, 772-777. [CrossRef]

56. Li, C.; Kouvelis, P. Flexible and risk-mapping supply contracts under price uncertainty. Manag. Sci. 1999, 45, 1378-1398. [CrossRef]

57. Power, G.; Burris, M.; Vadali, S.; Vedenov, D. Valuation of strategic options in PPPs. Transp. Res. Part A Police Pract. 2016, 90, 50-68. [CrossRef]

58. Liu, J.; Yu, X.; Cheah, C. Pricing mechanism of early termination of PPP projects based on real option theory. J. Manag. Eng. 2017, 33, 04017035. [CrossRef]

59. Iyer, K.C.; Sagheer, M. A real options based traffic risk mitigation model for build-operate-transfer highway projects in India. Constr. Manag. Econ. 2010, 29, 771-779. [CrossRef]

60. Campbell, J.A. Real options analysis of the timing of IS investment decisions. Inf. Manag. 2002, 39, 337-344. [CrossRef]

61. Benaroch, M. Option-based management of technology investment risk. IEEE Trans. Eng. Manag. 2001, 48, 428-444. [CrossRef]

62. Benaroch, M.; Kauffman, R.J. A case for using real options pricing analysis to evaluate information technology project investments. Inf. Sys. Res. 1999, 10, 70-86. [CrossRef] 
63. Schwartz, E.S.; Moon, M. Rational pricing of internet companies. Financ. Anal. J. 2000, 56, 62-75. [CrossRef]

64. Ketchen, D.J.; Ireland, R.D.; Snow, C.C. Strategic entrepreneurship, collaborative innovation, and wealth creation. Strateg. Entrep. J. 2007, 1, 371-385. [CrossRef]

65. O'Brien, J.P.; Folta, T.B.; Johnson, D.R. A real options perspective on entrepreneurial entry in the face of uncertainty. Manag. Decis. Econ. 2003, 24, 515-533. [CrossRef]

66. Ireland, R.D.; Hitt, M.A.; Sirmon, D.G. A model of strategic entrepreneurship: The construct and its dimensions. J. Manag. 2003, 29, 963-989.

67. Cruz Rambaud, S.; Sánchez Pérez, A.M. A mathematical approach to the deferment option of an investment project. Manag. Decis. Econ. 2019, 40, 639-650. [CrossRef]

68. Cruz Rambaud, S.; Sánchez Pérez, A.M. The option to expand a project: Its assessment with the binomial options pricing model. Oper. Res. Perspect. 2016, 28, 139-151. [CrossRef]

69. Cruz Rambaud, S.; Sánchez Pérez, A.M. An assessment of the option to reduce the investment in a project by the binomial pricing model. Eng. Econ. 2017, 28, 514-523. [CrossRef]

70. Cruz Rambaud, S.; Sánchez Pérez, A.M. Assessing the option to abandon an investment project by the binomial options pricing model. Adv. Decis. Sci. 2016, 2016, 7605909. [CrossRef]

71. Meléndez Rodríguez, J.C.; López Pascual, J.; Cañamero, P.; García, F.P. An overview of earned value management in airspace industry. In Proceedings of the Tenth International Conference on Management Science and Engineering Management. Advances in Intelligent Systems and Computing; Springer: Berlin/Heidelberg, Germany, 2017; Volume 502, pp. 1465-1477. [CrossRef]

72. López Pascual, J.; Meléndez Rodríguez, J.C.; Cruz Rambaud, S. The Enhanced-Earned Value Management (E-EVM) model: A proposal for the aerospace industry. Symmetry 2021, 13, 232. [CrossRef]

73. Royal Academy of Engineering and Royal Aeronautical Society. Innovation in Aerospace; Royal Academy of Engineering: London, UK, 2014.

74. Casault, S. Real Option Pricing Model Applied to Industrial and Regional Benefits Policy. Ph.D. Thesis, University of Ottawa, Ottawa, ON, Canada, 2010.

75. Lipke, W. Schedule is different. Meas. News 2003, 31, 10-15.

76. Lipke, W.; Zwikael, O.; Henderson, K.; Anbari, F. Prediction of project outcome the application of statistical methods to earned value management and earned schedule performance indexes. Int. J. Proj. Manag. 2009, 27, 400-407. [CrossRef]

77. Lipke, W. Earned schedule-Ten years after. Meas. News 2013, 3, 15-21.

78. Khamooshi, H.; Golafshani, H. EDM: Earned duration management, a new approach to schedule performance management and measurement. Int. J. Proj. Manag. 2014, 32, 1019-1041. [CrossRef]

79. Dodson, M.; Defavari, G.; de Carvalho, V. Quality: The third element of earned value management. Procedia Comput. Sci. 2015, 64, 932-939. [CrossRef]

80. Hendiania, S.; Bagherpoura, M.; Mahmoudib, A.; Liaoc, H. Z-number based earned value management (ZEVM): A novel pragmatic contribution towards a possibilistic cost-duration assessment. Comput. Ind. Eng. 2020, 143, 106430. [CrossRef]

81. SDGs \& Sectors: A review of the business opportunities. In A Report for the Business E Sustainable Development Commission; Corporate Citizenship: London, UK, 2016.

82. United Nations. International Standard Industrial Classification of all Economic Activities (ISIC). In Department of Economic E Social Affairs. Statistics Division; Statistical Papers, Series M; United Nations: New York, NY, USA, 2008; No. $4 /$ Rev. 4.

83. European Union Aviation Safety Agency. 2021. Available online: https:/ / www.easa.europa.eu (accessed on 24 April 2021).

84. Federal Aviation Administration. 2021. Available online: https://www.faa.gov (accessed on 24 April 2021).

85. Caron, F.; Ruggeri, F.; Merli, A. A Bayesian approach to improve estimate at completion in earned value management. Proj. Manag. J. 2013, 44, 3-16. [CrossRef] 